\title{
Sintesis dan Uji Mekanik Epoksi Termodifikasi Poliuretan Berbasis Ester Gliserol Monooleat
}

\section{Synthesis and Mechanical Properties of Polyurethane-Modified Epoxy Based on Glycerol Monooleate Ester}

\author{
Muhammad Ghozali ${ }^{1}$, L. R. Fauzi ${ }^{3}$, Evi Triwulandari ${ }^{1}$ \\ ${ }^{1}$ Pusat Penelitian Kimia-LIPI, Kawasan PUSPIPTEK Serpong, Tangerang Selatan, Indonesia 15314 \\ ${ }^{2}$ Universitas Islam Negeri (UIN) Syarif Hidayatullah, Jakarta \\ Corresponding author : muhammad.ghozali@lipi.co.id
}

\begin{tabular}{|c|}
\hline A RT I CLE INFO \\
\hline Article history \\
\hline Received date :13 January 2016 \\
\hline Revised date : 17 May 2016 \\
\hline Accepted date :10 June 2016 \\
\hline Available online at: \\
\hline http://kimia.lipi.go.id/inajac/index.php \\
\hline Kata kunci: \\
\hline $\begin{array}{l}\text { epoksi, esterifikasi, poliuretan, } \\
\text { gliserol monooleat }\end{array}$ \\
\hline Keywords: \\
\hline $\begin{array}{l}\text { epoxy, esterification, polyurethane, } \\
\text { glycerol monooleate }\end{array}$ \\
\hline
\end{tabular}

\section{Abstrak}

Modifikasi epoksi telah dilakukan untuk mengatasi kelemahan epoksi terutama dalam hal kekuatan tarik. Epoksi termodifikasi poliuretan (ETP) merupakan salah satu cara yang telah dilakukan. Pada penelitian ini modifikasi epoksi menggunakan poliuretan dilakukan dengan cara menambahkan senyawa ester gliserol monooleat sebagai poliol. Sintesis ester gliserol monooleat (GMO) dilakukan melalui reaksi esterifikasi gliserol dengan asam oleat dengan katalis asam sulfat dengan rendemen $80 \%$. Sintesis Epoksi Termodifikasi Poliuretan Berbasis Ester Gliserol Monooleat (ETPGMO) dilakukan dengan cara mereaksikan, epoksi, tolonat dan GMO pada suhu $50^{\circ} \mathrm{C}$ selama 30 menit, menghasilkan rendemen $80 \%$. Karakterisasi gugus fungsi dan struktur GMO dan ETPGMO dilakukan dengan FTIR dan NMR. Pembuatan film ETPGMO dilakukan dengan menambahkan hardener. Hasil analisa sifat mekanik menunjukkan bahwa kekuatan tarik ETPGMO lebih tinggi dua kali lipat dibandingkan epoksi yang disebabkan hadirnya poliuretan.

\begin{abstract}
Polyurethane-Modified Epoxy (PME) is one of methods in epoxy modification to address some epoxy drawbacks, especially on tensile strength. In this research, epoxy modification using polyurethane has been performed by adding glycerol monooleate ester as polyol. Synthesis of glycerol monooleate ester (GMO) is done via an esterification reaction glycerol with oleic acid with sulfuric acid as catalyst with a yield of $80 \%$. Synthesis of PME based on Ester Glycerol Mono-Oleate (PMEGMO) is performed by reacting epoxy, tolonat and GMOs at $50^{\circ} \mathrm{C}$ for 30 minutes and produce a yield of $80 \%$ Characterization of functional groups and structure of the synthesized GMO and PMEGMO are done by using FTIR and NMR. PMEGMO films is made by adding hardener. Analysis results of the mechanical properties show that the synthesized PMEGMO has two-fold higher tensile strength compared to unmodified epoxy caused by the presence of polyurethane.

(C 2016 Indonesian Journal of Applied Chemistry. This is an open access article under the CC BY-NC-SA license.
\end{abstract}




\section{PENDAHULUAN}

Epoksi dan poliuretan merupakan material yang paling umum digunakan dalam industri pelapis.Epoksi memiliki memiliki sifat ketahanan korosi dan ketahanan termal yang baik, tetapi epoksi juga memiliki kekuatan tarik yang rendah dan rapuh.Sedangkan poliuretan memiliki sifat elastis yang baik dan tahan terhadap sinar terhadap sinar ultraviolet. Usaha untuk meningkatkan kinerja dan performa epoksi, terutama untuk meningkatkan kekuatan tarik dan fleksibilitas epoksi telah dilakukan dengan cara memodifikasi epoksi menggunakan poliuretan.

Penelitian tentang modifikasi epoksi menggunakan poliuretan telah dilakukan, antara lain penelitian tentang pengaruh berbagai jenis poliuretan terhadap struktur dan sifat mekanik pada epoxy [1], evaluasi sifat dan analisis struktur sistem pelapis poliuretan-epoksi [2], pembuatan dan evaluasi sifat nanokomposit epoksi/montmorillonite termodifikasi poliuretan [3], kombinasi poliuretan dan montmorillonite dan poliuretan sebagai modifier epoksi [4].Modifikasi epoksi dengan poliuretan tanpa pembuatan prepolimer poliuretan juga telah dikembangkan.Penelitian tentang pembuatan epoksi termodifikasi poliuretan telah dilakukan dengan caramereaksikan epoksi dengan poliuretan menggunakan berbagai jenis poliol, antara lain poliol akrilik, gliserol, propandiol [5],polipropilen glikol [6] dan pengaruh variasi suhu dan komposisi poliuretan pada modifikasi epoksi menggunakan poliol akrilik juga telah dilakukan [7].Kestabilan termal beberapa polimer semi-interpenetrated berbasis resin epoksi dan poliuretan aromatikjuga telah dipelajari [8]. Peningkatan sifat fleksibilitas epoksi juga dapat dilakukan dengan cara menambahkan elastomer biodegradable $[9,10]$ dan karet [11] pada epoksi.

Penggunaan turunan minyak nabati untuk aplikasi material cat dan pelapis telah dikembangkan dalam beberapa tahun terakhir.Minyak nabati merupakan salah satu bahan baku yang dapat digunakan untuk industri kimia, antara lain industri kosmetik, sabun dan industri cat dan pelapis. Selain dapat digunakan sebagai binder untuk cat dan pelapis, turunan minyak nabati juga memiliki sifat sebagai penghalang korosi alami. Saat ini banyak penelitian dilakukan untuk mengembangkan, memanfaatkan dan memberikan nilai tambah terhadap turunan minyak nabati. Pada umumnya penelitian tersebut difokuskan untuk mendapatkan sifat baru dan meningkatkan performa. Turunan minyak nabati memiliki beberapa keunggulan yang disebabkan adanya gugus fungsional seperti ikatan rangkap, epoksi, hidroksil, ester dan gugus fungsi lainnya yang dapat digunakan sebagai gugus aktif untuk transformasi kimia, fisik, meningkatkan stabilitas kimia dan merupakan material yang ramah lingkungan [12]. Turunan minyak nabati dan poliuretan dapat digunakan sebagai matriks organik untuk memproduksi material pelapis hibrid organikanorganik, material pelapis nanokomposit [13] serta telah digunakan untuk sistem pelapis poliuretan berbasis minyak nabati $[14,15]$.

Pada penelitian ini, dalam rangka meningkatkan nilai tambah salah satu turunan minyak nabati yaitu asam oleat, akan digunakan sebagai senyawa penyusun poliuretan berbasis poliol minyak nabati. Proses modifikasi epoksi dilakukan menggunakan poliuretan yang tersusun dari senyawa ester asam oleat, yaitu gliserol monooleat (GMO). Sintesis ester GMO dibuat dengan tetap mempertahankan adanya gugus hidroksil yang nantinya akan membentuk ikatan uretan dengan gugus isosianat $\mathrm{N}=\mathrm{C}=\mathrm{O}$ pada tolonat. Sedangkan, sintesis epoksi termodifikasi poliuretan-gliserol monooleat (ETPGMO) dilakukan dengan mereaksikan epoksi, tolonat dan GMO.

\section{METODOLOGI PENELITIAN}

\subsection{Bahan}

Bahan-bahan yang digunakan antara lain asam oleat, gliserol (Merck), asam sulfat (Merck), $n$-heksana (Merck), dibutiltin dilaurat (Sigma Aldrich), epoksi diglisidil eter bisfenol A dengan berat molekul 236,1 gr/mol (PT. Sigma Utama), tolonat HDT (PT. Sigma Utama), dan versamid 140 (PT. Sigma Utama). 
J.Kim.Terap.Indones., 18(1), pp. $45-54$, June 2016

\subsection{Metode}

\subsubsection{Esterifikasi Glierol Monooleat (GMO)}

Sintesis GMO dilakukan dengan cara mereaksikan gliserol dan asam oleat dengan perbandingan mol 1: 1 pada labu leher tiga yang dilengkapi dengan pendingin dan pengaduk serta denstak untuk menarik air yang dihasilkan dari reaksi esterifikasi, sehingga kesetimbangan reaksi bergeser kearah pembentukan GMO. Reaksi dilakukan pada suhu $180^{\circ} \mathrm{C}$ selama 150 menit dengan bantuan katalis asam sulfat sebanyak $1 \%$ berat total (asam oleat dan gliserol). Produk GMO yang dihasilkan kemudian dilarutkan dalam $n$ heksana dan dicuci menggunakan larutan $\mathrm{NaCl}$ $5 \%$ (berat/berat) untuk memisahkan asam sulfat dalam produk GMO sampai pH GMO netral. Tujuan pemakaian $\mathrm{NaCl}$ yaitu untuk mencegah terjadinya emulsi pada saat pencucian. Kemudian, $n$-heksana yang terdapat dalam produk GMO yang sudah netral dipisahkan dengan metode evaporasi.

\subsubsection{Epoksi Termodifikasi Poliuretan - Gliserol Monooleat (ETPGMO)}

Sintesis ETPGMO dibuat dengan cara mereaksikan secara bersama-sama antara epoksi, tolonat dan GMO dalam labu leher tiga pada $50^{\circ} \mathrm{C}$ selama 30 menit dengan kecepatan pengadukan sekitar $200 \mathrm{rpm}$ [5]. Perbandingan mol epoksi : tolonat : GMO adalah $1: 0,03$ : 0,07. Katalis dibutiltindilaurat (DBTL) $0,1 \%$ (berat DBTL/berat total) ditambahkan untuk mempercepat terjadinya reaksi. Produk ETPGMO yang dihasilkan sekitar $80 \%$.

\subsubsection{Karakterisasi GMO dan ETPGMO}

Analisis Fourier Transform Infrared (FTIR) dilakukan dengan instrumen IR Prestige-21 Shimadzu untuk mempelajari adanya perubahan gugus fungsi dengan cara membandingkan spektrum epoksi dengan ETPGMO. Sedangkan analisis struktur kimia digunakan spektrum proton dan karbon dengan menggunakan NMR JEOL 500 menggunakan pelarut deuterium aseton untuk epoksi dan
p-ISSN: 0853-2788, e-ISSN: 2527-7669

Accreditation number : 540/AU1/P2MI LIPI/06/2013

deuterium kloroform untuk GMO dan ETPGMO.

\subsubsection{Film ETPGMO}

Film ETPGMO dibuat dengan menambahkan versamid 140 sebagai curing agent (hardener) denganperbandingan berat antara ETPGMO dengan curing agent yaitu 2:1 [5]. Pembuatan film dilakukan di atas permukaan papan polietilen dengan ketebalan film $0,3 \mathrm{~mm}$. Film yang dihasilkan kemudian dianalisis uji kuat tarik menggunakan alat Ultimate Testing Machine (UTM).

\section{HASIL DAN PEMBAHASAN}

Pembuatan epoksi termodifikasi poliuretan berbasis ester sawit dibuat dengan memodifikasi epoksi dengan tolonat dan senyawa ester. Senyawa ester dibuat dengan mereaksikan asam oleat dan gliserolsehingga membentuk GMO. Pembuatan GMO dibuat dengan tetap mempertahankan gugus hidroksi dan dilakukan dengan perbandingan 1:1 (mol/mol), hal ini bertujuan agar hanya satu gugus hidroksi $\mathrm{OH}$ pada $\mathrm{C}-1$ dari gliserol yang terikat pada asam oleat, sehingga masih ada ada gugus hidroksi $\mathrm{OH}$ lainnya yang diharapkan akan bereaksi dengan salah satu gugus isosianat $\mathrm{N}=\mathrm{C}=\mathrm{O}$ dari tolonat untuk membentuk ikatan uretan. Gugus isosianat $\mathrm{N}=\mathrm{C}=\mathrm{O}$ lainnya dari tolonat diharapkan dapat bereaksi dengan epoksi untuk membentuk epoksi termodifikasi poliuretan-gliserol monooleat (ETPGMO).

\subsection{Sintesis Gliserol Monooleat (GMO)}

Sintesis GMO dilakukan melalui esterifikasi antara gliserol dengan asam oleat menggunakan katalis asam (gambar 1). Reaksi esterifikasi GMO dilakukan dengan perbandingan mol $1: 1$, agar hanya 1 gugus $\mathrm{OH}$ pada gliserol yang bereaksi dengan asam oleat, sehingga gugus $\mathrm{OH}$ lainnya dapat bereaksi dengan tolonat untuk membentuk ikatan uretan. Produk GMO yang dihasilkan sekitar $80 \%$.

Karakterisasi dengan FTIR digunakan untuk mengetahui adanya perubahan gugus fungsi yang terjadi pada produk hasil reaksi esterifikasi antara asam oleat dengan 
gliserol.Analisis FTIR asam oleat dan GMO dilakukan pada bilangan gelombang 400-4000<smiles>CCCCCCCC/C=C\CCCCCCCC(=O)O</smiles><smiles>OCC(O)CO</smiles>

Gliserol

\section{GMO}

Gambar 1. Reaksi Esterifikasi GMO

$\mathrm{cm}^{-1}$. Spektrum FTIR asam oleat dan GMO ditunjukkan pada gambar 2. Asam oleat memiliki gugus karbonil $\mathrm{C}=\mathrm{O}$ dari karboksilat - $\mathrm{COOH}$ pada rantainya.

Pada spektrum FTIR asam oleat (Gambar.2a), puncak serapan gugus karbonil ini muncul pada bilangan gelombang $1708 \mathrm{~cm}^{-}$ ${ }^{1}$,sedangkan pada spektrum FTIR GMO (Gambar.2b) muncul pada bilangan gelombang $1741 \mathrm{~cm}^{-1}$ yang merupakan senyawa ester. Adanya pergeseran puncak serapan dari bilangan gelombang $1708 \mathrm{~cm}^{-1}$ menjadi 1741 $\mathrm{cm}^{-1}$ menunjukkan bahwa reaksi esterifikasi telah berhasil menghasilkan GMO. Hal ini juga dibuktikan dengan munculnya puncak serapan baru pada bilangan gelombang $1168 \mathrm{~cm}^{-1}$ yang menunjukkan adanya gugus fungsi baru yaitu gugus C-O-C. Spektrum FTIR GMO juga menunjukkan adanya puncak serapan pada bilangan gelombang $3466 \mathrm{~cm}^{-1}$ yang menunjukkan adanya gugus hidroksil $(\mathrm{OH})$. Gugus hidroksil $\mathrm{OH}$ ini masih ada karena poliol dan asam oleat yang direaksikan dengan perbandingan mol $1: 1$, sehingga hanya satu gugus hidroksil dari poliol yang bereaksi.

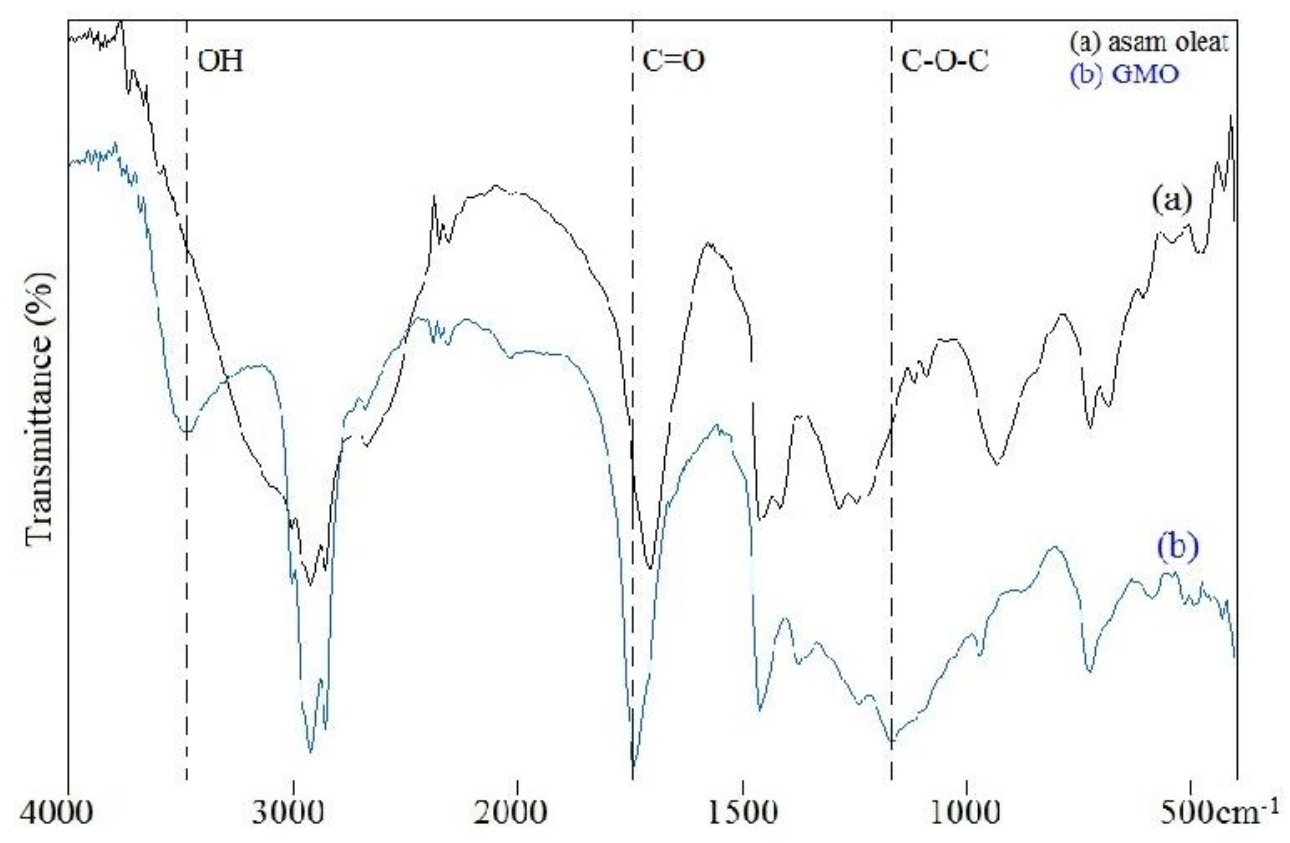


Gambar 2. Spektrum FTIR : a) Asam oleat; b) GMO

Analisis ${ }^{1} \mathrm{H}-\mathrm{NMR}$ dan ${ }^{13} \mathrm{C}-\mathrm{NMR}$ dilakukan untuk mengetahui pergeseran kimia proton $(\mathrm{H})$ dan pergeseran kimia karbon $(\mathrm{C})$ pada asam oleat dan GMO. Spektrum ${ }^{1} \mathrm{H}-\mathrm{NMR}$ dan ${ }^{13} \mathrm{C}$-NMR asam oleat dan GMO serta spektrum ${ }^{13} \mathrm{C}-\mathrm{NMR}$ ditunjukkan pada Gambar 3.

Pada spektrum H-NMR asam oleat (Gambar. 3a) terlihat pergeseran kimia proton pada 11,76 ppm yang menunjukkan adanya $\mathrm{H}$ yang berasal karboksilat, sedangkan pada spektrum H-NMR GMO (Gambar. 3b) puncak pada pergeseran kimia proton tersebut tidak muncul, hal ini menunjukkan bahwa gugus karboksilat telah menjadi ester. Munculnya pergeseran kimia proton baru pada 3,39-4,19 ppm yang menunjukkan adanya $\mathrm{H}$ yang terikat pada atom C1-C3 yang berasal dari gliserol telah menjadi ester. Pergeseran kimia proton pada 4,16 (1H, d, 5,15 Hz) ppm dan 4,19

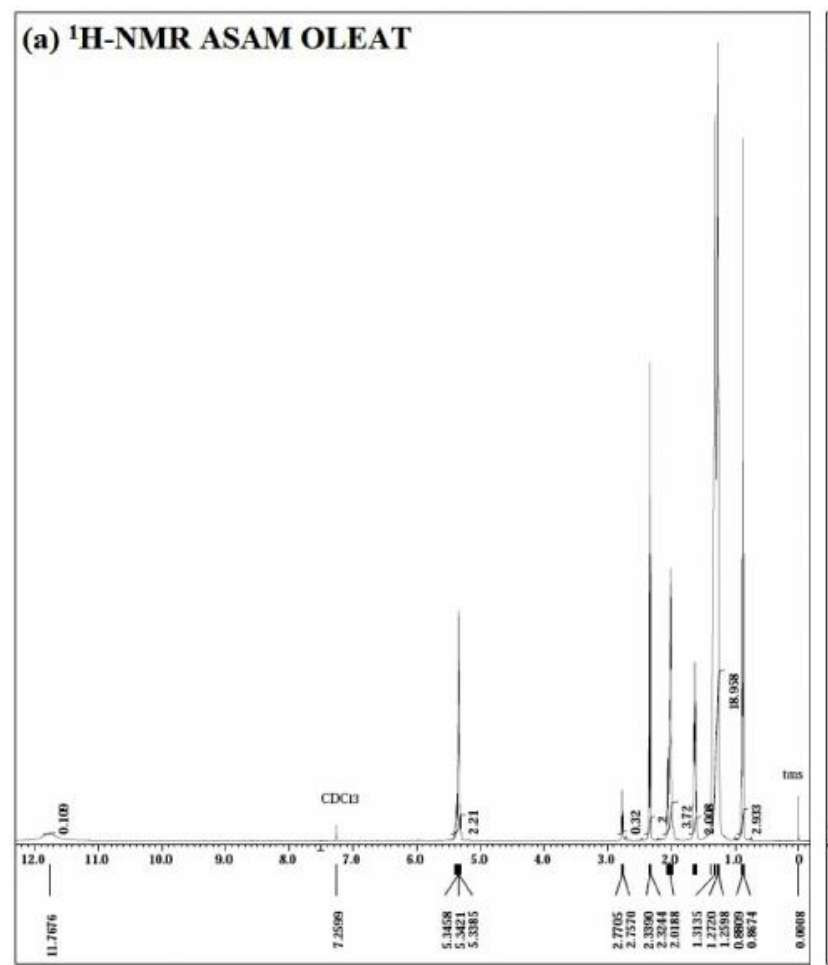

\section{(b) ${ }^{1}$ H-NMR GMO}
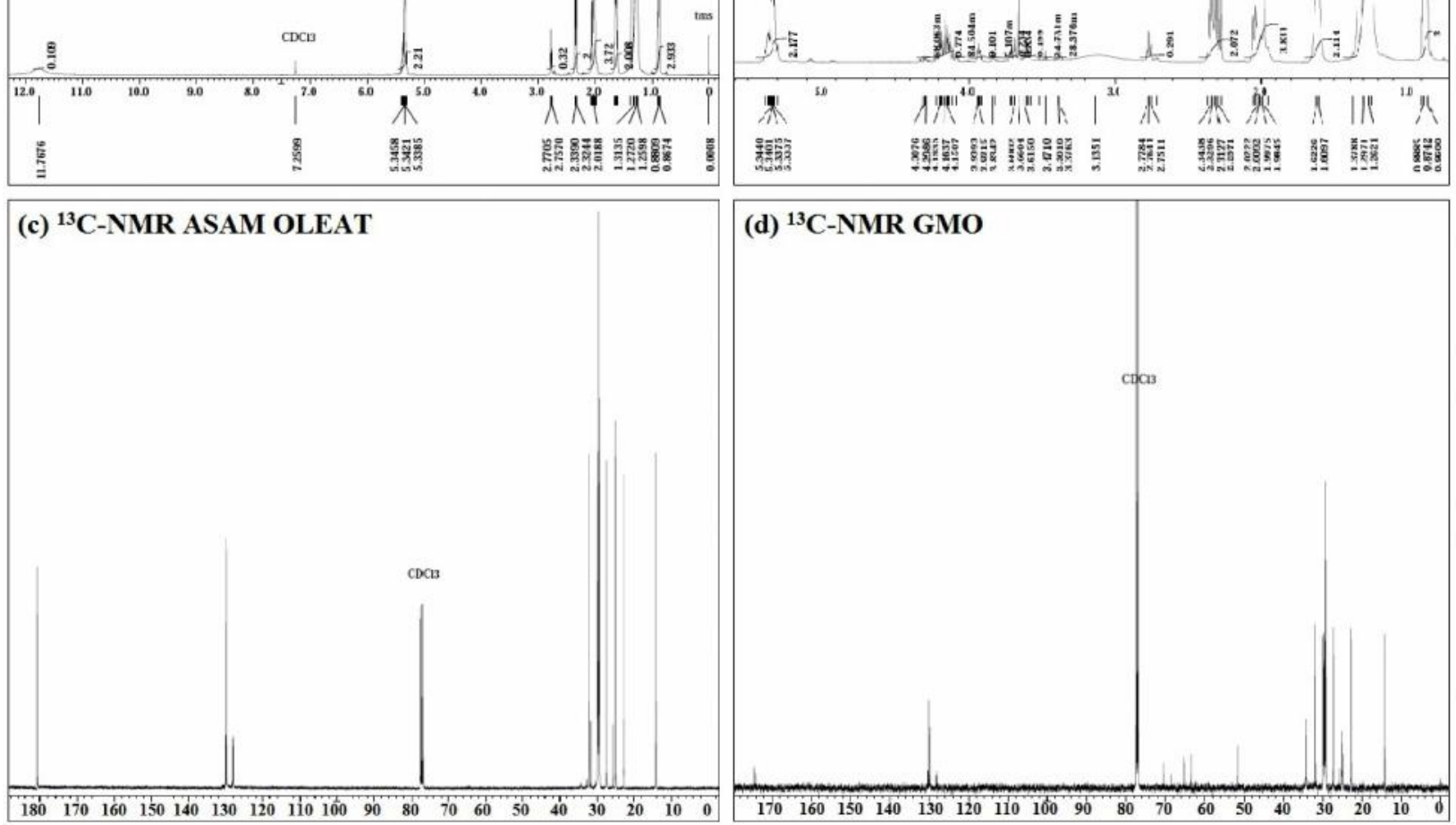

Gambar 3. Spektrum NMR : a) ${ }^{1} \mathrm{H}-\mathrm{NMR}$ Asam oleat; b) ${ }^{1} \mathrm{H}-\mathrm{NMR}$ GMO; c) ${ }^{13} \mathrm{C}-\mathrm{NMR}$ Asam oleat; dan d) ${ }^{13} \mathrm{C}-\mathrm{NMR}$ GMO 
$(1 \mathrm{H}, \mathrm{d}, 6,5 \mathrm{~Hz})$ ppm ini merupakan gugus $\mathrm{CH}_{2}$ pada C-1 dan menjadi downfield karena dipengaruhi adanya gugus karbonil dari asam oleat. Hal ini membuktikan bahwa telah terjadi ikatan antara gliserol pada C-1 dengan asam oleat dan membentuk GMO. Pada GMO (Gambar. 3d) muncul pergeseran kimia karbon pada 63,49 ppm, 65,22 ppm dan 70,44 ppm yang mengindikasikan adanya atom-atom $\mathrm{C}$ yang berasal dari gliserol. Pada gliserol seharusnya pergeseran kimia karbon hanya muncul pada $63,49 \mathrm{ppm}$ dan $70,44 \mathrm{ppm}$, tetapi pada GMO muncul pergeseran kimia karbon pada 65,22 ppm, hal ini disebabkan karena atom $\mathrm{C} 1$ pada gliserol telah terikat dengan asam oleat sehingga menyebabkan puncak pergeseran kimia bergeser kearah medan lebih rendah. Pergeseran kimia proton dan karbon diatas membuktikan bahwa telah terjadi reaksi antara asam oleat dengan gliserol dan membentuk GMO.

\subsection{Sintesis Epoksi Poliuretan-Gliserol (ETPGMO)}

\section{Termodifikasi Monooleat}

Spektrum FTIR resin epoksi (Gambar. 4a) menunjukkan adanya puncak serapan pada bilangan gelombang $3506 \mathrm{~cm}^{-1}$ yang menunjukkan gugus hidroksil $(\mathrm{OH})$ dari resin epoksi, tetapi pada ETPGMO (Gambar. 4c) puncak serapan tersebut bergeser ke bilangan gelombang $3398 \mathrm{~cm}^{-1}$ dan puncaknya lebih tajam, hal ini menunjukkan masih ada sisa gugus $\mathrm{OH}$ yang berasal dari GMO dan juga menunjukkan adanya gugus $\mathrm{NH}$ yang berasal dari ikatan uretan $-\mathrm{NH}-\mathrm{C}=\mathrm{O}-\mathrm{O}-$ yang mengindikasikan telah terjadi reaksi antara isosianat $(\mathrm{N}=\mathrm{C}=\mathrm{O})$ dari tolonat dengan $\mathrm{OH}$ dari epoksi maupun ETPGMO.Spektrum ETPGMO juga menunjukkan adanya puncak serapan pada bilangan gelombang $451 \quad \mathrm{~cm}^{-1}$ yang menunjukkan gugus -C-N-C-. Gugus -C-N-Cberasal dari reaksi isosianat $(\mathrm{N}=\mathrm{C}=\mathrm{O})$ dengan $\mathrm{OH}$ dari epoksi dan ETPGMO sehingga mengakibatkan ikatan rangkap $\mathrm{N}=\mathrm{C}$ dari isosianat berubah menjadi ikatan ikatan tunggal -NH-C- dan membentuk ikatan C-NH-C=O-O-. Puncak serapan baru juga muncul pada bilangan gelombang $1691 \mathrm{~cm}^{-1}$ dan $1724 \mathrm{~cm}^{-1}$ yang menunjukkan gugus karbonil $\mathrm{COO}$ yang berasal dari ikatan uretan $-\mathrm{NH}-\mathrm{C}=\mathrm{O}-\mathrm{O}$.Hal-hal tersebut diatas telah membuktikan bahwa ikatan uretan telah terbentuk dari reaksi antara isosianat $(\mathrm{N}=\mathrm{C}=\mathrm{O})$ dari tolonat dengan $\mathrm{OH}$ dari epoksi dan ETPGMO.

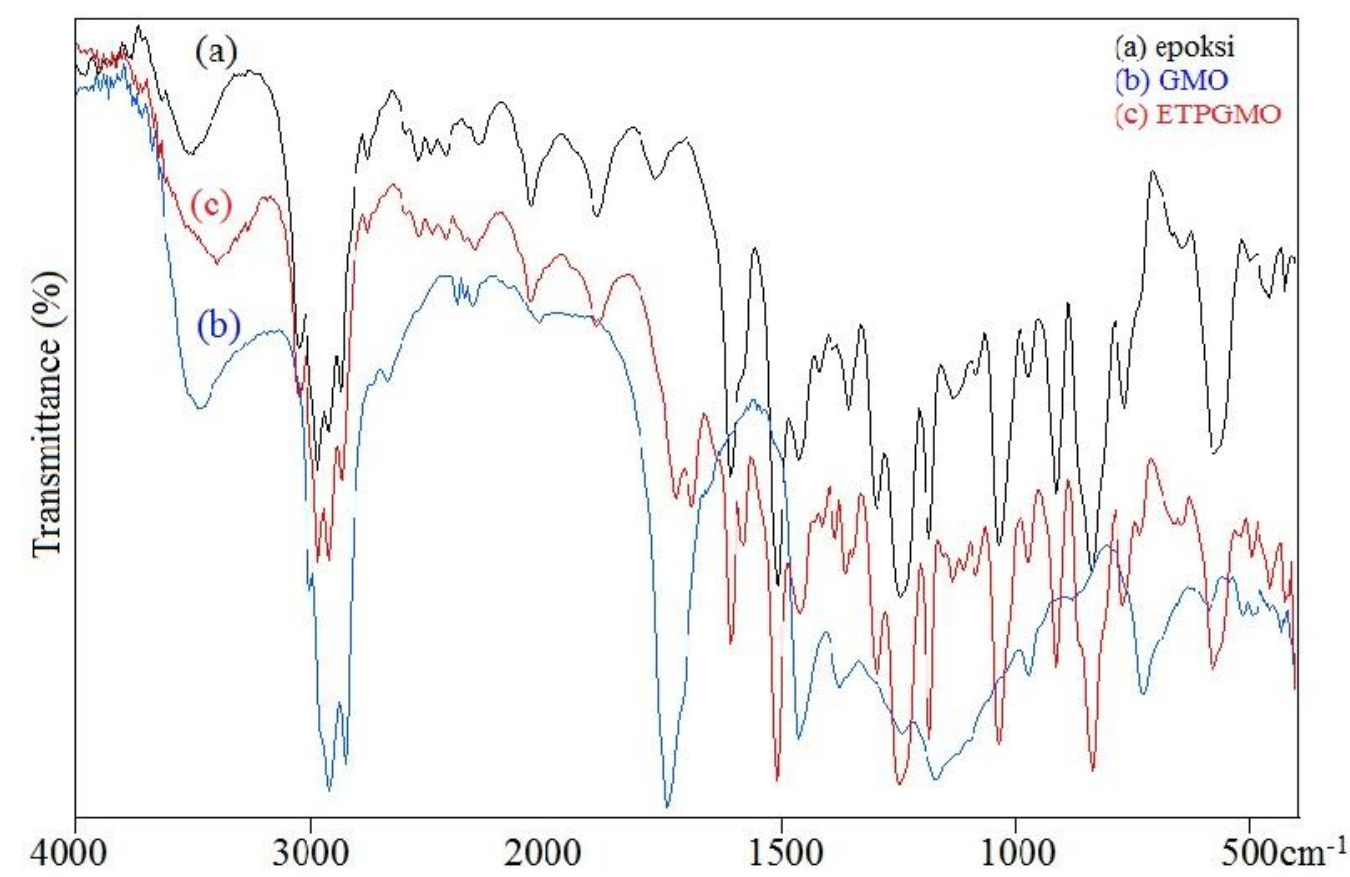


Gambar 4. Spektrum FTIR : a) Epoksi; b) GMO dan c) ETPGMO

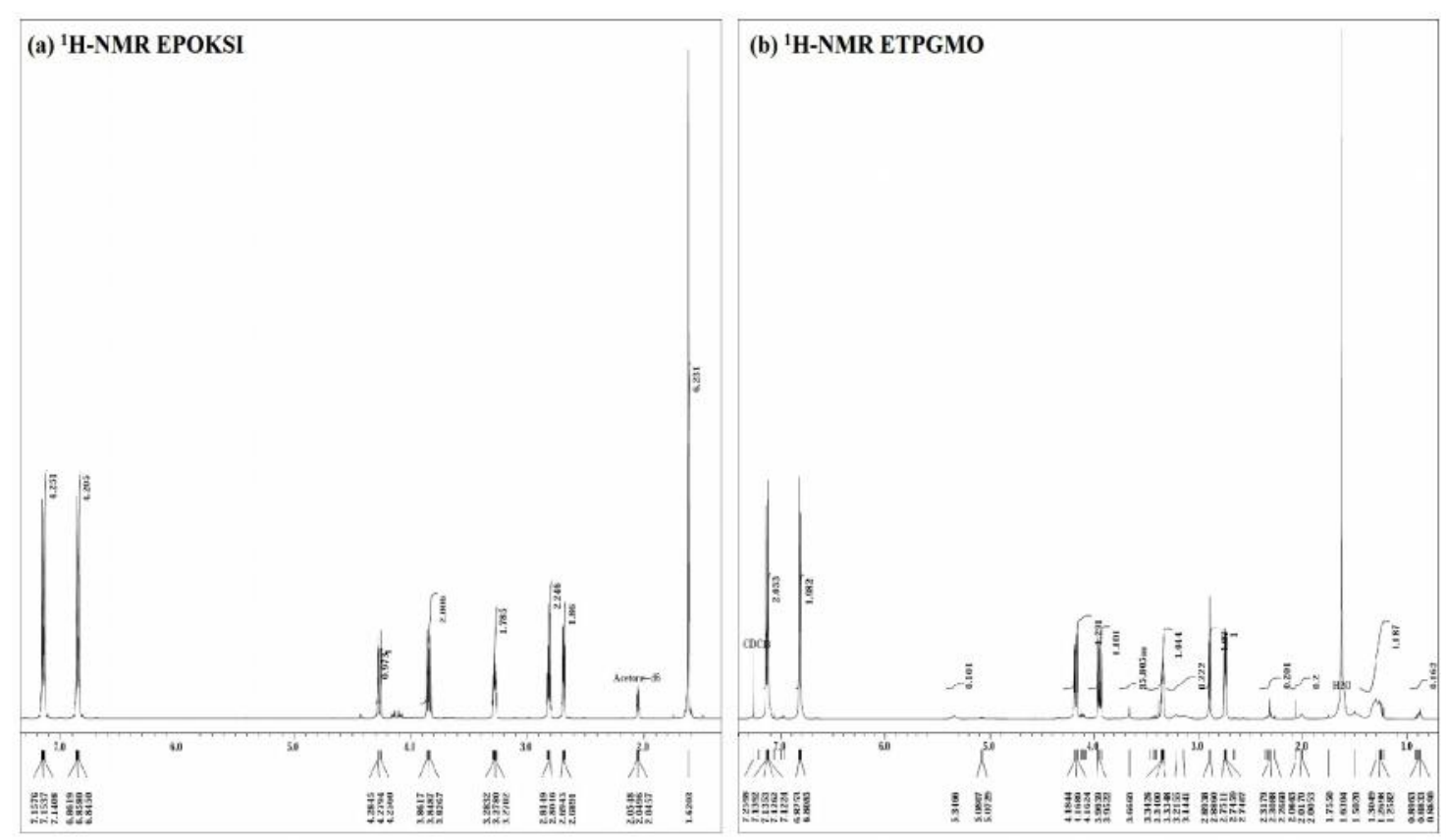

Gambar 5. Spektrum NMR : a) ${ }^{1} \mathrm{H}$-NMR Epoksi dan b) ${ }^{1} \mathrm{H}$-NMR ETPGMO

Analisa struktur kimia pada epoksi dan ETPGMO dilakukan menggunakan analisa ${ }^{1} \mathrm{H}$ NMR untuk mengetahui pergeseran kimia proton yang terjadi pada ETPGMO dengan membandingkan pergeseran kimia proton yang terjadi pada epoksi dan ETPGMO (Gambar. 5).

Pada spektrum ${ }^{1} \mathrm{H}-\mathrm{NMR}$ ETPGMO (Gambar. 5b) muncul beberapa pergeseran kimia proton baru, yaitu pada 0,$88 ; 1,26 ; 1,3$; 2,06; 3,18; 2,31; 3,66, 5,07 dan 5,34 ppm. Pergeseran kimia proton 0,88 ppm menunjukkan ikatan $-\mathrm{C}_{3} \underline{3}$ yang berasal dari atom-atom $\mathrm{H}$ yang terikat pada atom- $\mathrm{CH}_{3}$ pada ujung GMO, pergeseran kimia proton 1,26 ppm menunjukkan ikatan $-\mathrm{CH}_{2}$ yang berasal dari ikatan $\mathrm{C}-\underline{\mathrm{C}}_{2}-\mathrm{C}$ pada $\mathrm{GMO}$ dan tolonat sedangkan 1,30 ppm; menunjukkan ikatan $\mathrm{C}_{\mathrm{H}_{2}}$ yang berasal dari atom $\mathrm{H}$ yang terikat pada atom $\mathrm{C}$ sebelum atom $\mathrm{C}$ ujung GMO ($\left.\mathrm{CH}_{2}-\mathrm{CH}_{3}\right)$ dan pergeseran kimia proton pada 2,06 ppm mengindikasikan ikatan $-\mathrm{C}_{2}-$ yang berasal atom-atom $\mathrm{H}$ yang terikat pada atom $\mathrm{C}$ pada ikatan $-\underline{\mathrm{C}}_{2}-\mathrm{CH}=\mathrm{CH}-\underline{\mathrm{H}}_{2}-$ pada GMO. Pergeseran Kimia proton pada 3,18 ppm pada ETPGMO menunjukkan ikatan $-\mathrm{CH}_{2}-$ yang berasal atom-atom $\mathrm{H}$ yang terikat pada atom $\mathrm{C}$ yang terikat pada ikatan $-\mathrm{CH}_{2}-\mathrm{NH}-$ dan pergeseran kimia proton pada 2,31 ppm mengindikasikan ikatan $-\mathrm{CH}_{2}-$ yang berasal atom-atom $\mathrm{H}$ yang terikat pada atom $\mathrm{C}$ pada ikatan - $\underline{\mathrm{C}}_{2}-\mathrm{COO}-$. Pergeseran kimia proton baru juga muncul pada nilai pergeseran kimia proton 3,66 ppm yang merupakan nilai pergeseran kimia proton dari ikatan $-\mathrm{OH}$ yang berasal atom $\mathrm{H}$ yang terikat pada atom $\mathrm{O}$ pada ikatan C-2-OH yang berasal dari GMO. Nilai pergeseran kimia proton ini tidak bergeser ke arah downfield karena atom $\mathrm{H}$ pada $\mathrm{C}-2$ ini tidak terpengaruh adanya gugus karbonil seperti halnya atom C-1 pada GMO.

Pada epoksi (Gambar.5a) terdapat pergeseran kimia proton pada 4,25 yang menunjukkan ikatan - $\mathrm{CH}$ - yang berasal dari atom $\mathrm{H}$ yang terikat pada atom $\mathrm{C}$ pada ikatan $\mathrm{C}$ H-OH yang berasal dari epoksi, sedangkan pada ETPGMO (Gambar. 5b), nilai pergeseran kimia proton ini bergeser ke arah medan yang lebih rendah, yaitu pada pergeseran kimia proton pada 5,07 ppm yang menunjukkan ikatan - $\mathrm{CH}$ - yang berasal dari atom $\mathrm{H}$ yang terikat pada atom $\mathrm{C}$ pada ikatan $-\mathrm{CH}_{2}-\mathrm{CHO}-\mathrm{CH}_{2}-$. Pergeseran kimia ini muncul karena disebabkan adanya reaksi antara gugus hidroksil $\mathrm{OH}$ pada ikatan C-OH epoksi dengan gugus isosianat 
$\mathrm{N}=\mathrm{C}=\mathrm{O}$ pada tolonat membentuk ikatan uretan $\quad-\mathrm{NH}-(\mathrm{C}=\mathrm{O})-\mathrm{O}-\mathrm{C} \underline{\mathrm{H}}-\mathrm{CH}_{2}-$. Pembentukan ikatan

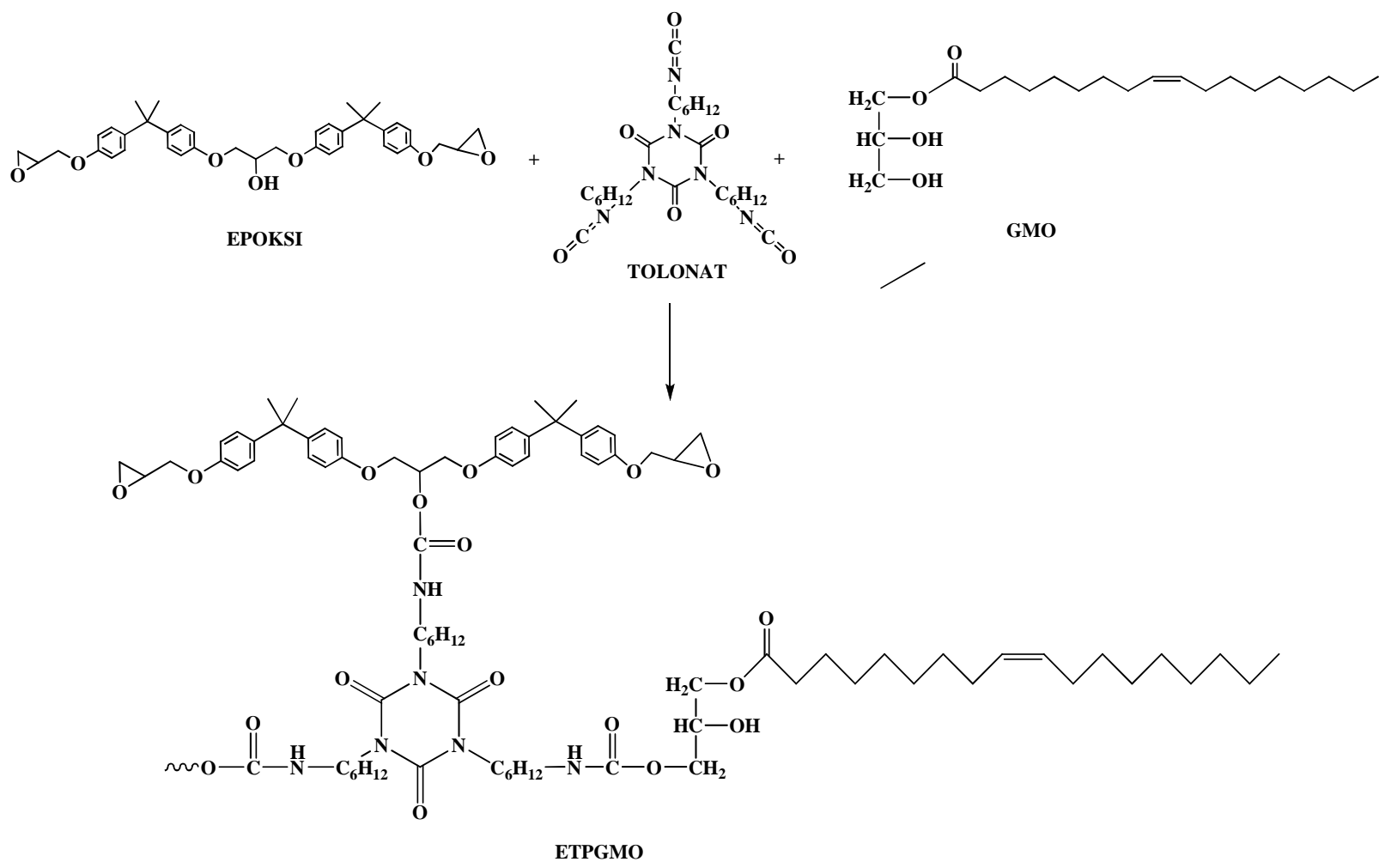

Gambar 6. Reaksi Pembentukan ETPGMO

uretan inilah yang menyebabkan munculnya nilai pergeseran kimia proton ke arah medan yang lebih rendah. Pada ETPGMO juga munculnilai pergeseran kimia proton baru pada 5,34 ppm menunjukkan atom-atom $\mathrm{H}$ yang terikat pada atom $\mathrm{C}$ pada ikatan rangkap $\mathrm{C} \underline{\mathrm{H}}=\mathrm{C} \underline{\mathrm{H}}-$ yang berasal dari GMO. Nilai-nilai pergeseran kimia proton diatas telah mengindikasikan bahwa telah terjadi reaksi antara epoksi, tolonat dan GMO membentuk ETPGMO.

\subsection{Uji Kuat Tarik}

Uji kuat tarik dilakukan untuk mengetahui daya tahan dari film ETPGMO hingga akhirnya putus. Resin epoksi memiliki nilai kuat tarik sebesar 69,61 kgf/cm ${ }^{2}$ [6]. Film ETPGMO memiliki kekuatan tarik lebih tinggi dibandingkan dengan resin epoksi. Nilai kuat tarik dari sampel ETPGMO sebesar 136,05 $\mathrm{kgf} / \mathrm{cm}^{2}$. Peningkatan nilai kuat tarik pada ETPGMO bila dibandingkan dengan resin epoksi disebabkan karena adanya plasticizing effect yang membuat material menjadi lebih elastis yang ditimbulkan dari penambahan poliuretan [16]. Hal ini menimbulkan hard segment dan soft segment pada epoksi yang akan menghalangi aliran plastis rantai polimer dan menghasilkan gaya pegas elastis yang berimbas pada nilai kuat tarik material tersebut [17]. Hard segment dan soft segment yang ada pada resin ETPGMO berasal dari reaksi crosslinking antara isosianat dan ester GMO. Reaksi ini akan berpengaruh terhadap nilai kuat tarik, karena struktur dari dua komponen mempengaruhi crosslinking density. Asam lemak jenuh umumnya menurunkan crosslinking density dan isosianat dalam bentuk aromatik seperti yang digunakan pada penelitian ini memiliki crosslinking density yang lebih baik jika dibandingkan dengan isosianat dalam bentuk alifatik. Gugus isosianat mengandung $\mathrm{R}-\mathrm{N}=\mathrm{C}=\mathrm{O}$, dengan $\mathrm{R}$ merupakan gugus aromatik maka kereaktifan isosianat sangat dipengaruhi oleh karakter positif atom karbon dan muatan negatif akan terdelokasi ke $\mathrm{R}$, dengan demikian, isosianat aromatik akan lebih reaktif daripada isosianat alifatik. Selain itu, sifat substituent pada isosianat aromatik 
juga menentukan kereaktifannya. Hasil penelitian sudah sesuai dengan yang diharapkan, yaitu dengan adanya penambahan poliuretan ke dalam struktur epoksi dapat meningkatkan sifat mekanik epoksi [1,2].

\section{KESIMPULAN}

Dari penelitian ini diketahui bahwa ETP dapat dimodifikasi dengan penambahan gugus ester yang berasal dari gliserol monooleat dan poliol. Hal ini dibuktikan dengan spektrum FTIR dan NMR. Peningkatan daya tarik ETPGMO yang dihasilkan lebih baik dibandingkan dengan resin epoksi yakni sebesar $136,05 \mathrm{kgf} / \mathrm{cm}^{2}$.

\section{DAFTAR PUSTAKA}

[1] M. Kostrzewa, B. Hausnerova, M. Bakar, and E. Siwek. 2011. Effects of Various Polyurethanes on the Mechanical and Structural Properties of an Epoxy Resin. Journal of Applied Polymer Science, Vol. 119, 2925-2932. Wiley Periodicals, Inc.

[2] M. Kostrzewa, B. Hausnerova, M. Bakar and M. Dalka. 2011. Property Evaluation and Structure Analysis of Polyurethane/Epoxy Graft Interpenetrating Polymer Networks. Journal of Applied Polymer Science, Vol. 122, 1722-1730. Wiley Periodicals, Inc.

[3] M. Bakar, M. Kostrzewa, B. Hausnerova, K. Sar. 2010. Preparation and Property Evaluation of Nanocomposites Based on Polyurethane-Modified

Epoxy/Montmorillonite Systems. Advances in Polymer Technology, Vol. 29, No. 4, 237-248. Wiley Periodicals, Inc.

[4] M. Kostrzewa, B. Hausnerova, M. Bakar, K. Pajak. 2011. Preparation and Characterization of an Epoxy Resin Modified by a Combination of MDIBased Polyurethane and Montmorillonite. Journal of Applied Polymer Science, Vol. 122, 3237-3247.VC 2011 Wiley Periodicals, Inc.

\section{Accreditation number : 540/AU1/P2MI LIPI/06/2013}

[5] M. Ghozali, E. Triwulandari dan A. Haryono. 2015. Preparation and Characterization of PolyurethaneModified Epoxy with Various Types of Polyol. Macromol.Symp.353, 154-160. www.ms-journal.de.

[6] M. Ghozali, A.H. Saputra, E. Triwulandari dan A. Haryono. 2014. Modifikasi Epoksi Dengan Poliuretan Tanpa Melalui Tahap Prepolimer Poliuretan. Jurnal Sains Materi Indonesia Vol. 15, No. 4, Juli 2014, hal. 208-213.

[7] E. Triwulandari dan M. Ghozali. 2013. Pembuatan Epoksi Termodifikasi Poliuretan Dari Poliol Akrilik Dengan Variasi Suhu Dan Komposisi Poliuretan. Jurnal Sains Materi Indonesia.Vol. 14, No. 2, Januari 2013, hal : 120 - 124.

[8] D. Rosu, L. Rosu dan C.D. Varganici. 2013. The thermal stability of some semiinterpenetrated polymer networks based on epoxy resin and aromatic polyurethane. Journal of Analytical and Applied Pyrolysis 100, 103-110.

[9] H. Yeganeh, M.M. Lakouraj dan S. Jamshidi. 2005. Synthesis and properties of biodegradable elastomeric epoxy modified polyurethanes based on poly(ecaprolactone) and poly(ethylene glycol). European Polymer Journal 41, 23702379.

[10] H. Yeganeh, M.M. Lakouraj dan S. Jamshidi. 2005. Synthesis and Characterization of Novel Biodegradable Epoxy-Modified Polyurethane Elastomers. Journal of Polymer Science: Part A: Polymer Chemistry, Vol. 43, 2985-2996.

[11] N. Chikhi, S. Fellahi, M. Bakar. 2002. Modification of epoxy resin using reactive liquid (ATBN) rubber. European Polymer Journal 38, 251-264.

[12] M. Alam, D. Akram, E. Sharmin, F. Zafar dan S. Ahmad. 2014.vegetable oil based eco-friendly coating materials. Arabian Journal of Chemistry. 7, 469-479. 
[13] D. Akram, E. Sharmin dan S. Ahmad. 2014.

Linseed polyurethane/tetraethoxyorthosilane/fume d silica hybrid nanocomposite coatings:Physico-mechanical and potentiodynamic polarization measurement studies. Progress in Organic Coatings 77, 957-964.

[14] X. Kong, G. Liu, H. Qi dan J.M. Curtis. 2013. Preparation and characterization of high-solid polyurethane coating systems based on vegetable oil derived polyols. Progress in organics coatings 76, 11511160.

[15] M. Alam dan N.M. Alandis. 2014. Corn oil based poly(ether amide urethane) coating material-synthesis, characterization and coating properties. Industrial Crops and Products 57, 17-28.

[16] A.B. Cherian, L.A. Varghese dan E.T. Thachil. 2007. Epoxy-Modified, Unsaturated Polyester Hybrid Networks. European Polymer Journal 43, 14601469.

[17] Lu, Yongshang, Richard C Larock. 2008. Soybean-Oil Based Waterborne Polyurethane Dispersions: Effects of Polyol Functionality and Hard Segment Content on Properties.

Biomacromolecules 9, 3332-3340. 